\title{
Person centered psychotherapy: An encounter with oneself or a confrontation with the Other?
}

\author{
Psicoterapia centrada na pessoa: \\ um encontro consigo mesmo ou \\ um embate com o Outro?
}

\author{
Emanuel Meireles VIEIRA \\ Francisco Pablo Huascar Aragão PINHEIRO²
}

\begin{abstract}
The paper discusses the possibilities of host of alterity in the therapeutic process of the Person Centered Approach. The debate is based on the ethics of Emmanuel Levinas, for whom subjectivity would be formed from the relationship with the absolute other. The therapeutic change process that aims to further integrate the experience by the self is questioned. On the other hand, from a reading of a Rogerian clinical case, it is pointed out the externality of experience as an estrangement that allows one to recreate themselves. This research shows the interiority eroded by the organism that arises as other-of-self, sieve for the experience. It is conclude that the person-centered psychotherapy, beyond an encounter with oneself, seems to point as one of its purposes the clash with the radically different. Such discussion alludes to a political repositioning of the Person Centered Approach in its ways to deal with the difference.
\end{abstract}

Uniterms: Alterity; Person-centered approach; Psychotherapy.

\section{Resumo}

O artigo discute a possibilidade do acolhimento da Alteridade no processo terapêutico da Abordagem Centrada na Pessoa. Tem-se como referência a ética de Emmanuel Lévinas, para quem a subjetividade seria constituída a partir da relação com o absolutamente outro. Questiona-se o processo de mudança terapêutica que visa uma maior integração da experiência pelo self. Em direção distinta, a partir de uma releitura de um caso clínico rogeriano, aponta-se a exterioridade da experiência como estranhamento que permite uma recriação de si. O relato analisado mostra a interioridade ser solapada pelo organismo que se coloca como um outro-de-si, crivo para as experiências. Conclui-se que a psicoterapia centrada na pessoa, além de um encontro consigo mesmo, parece apontar como um de seus efeitos o embate com radicalmente diferente. Tal discussão alude a um reposicionamento político da Abordagem Centrada na Pessoa em sua lida com a diferença.

Unitermos: Alteridade; Abordagem centrada na pessoa; Psicoterapia.

\section{$\nabla \nabla \nabla v$}

1 Universidade Federal do Pará, Faculdade de Psicologia. R. Augusto Correia, 1, Guamá, 66075-110, Belém, PA, Brasil. Correspondência para/Correspondence to: E.M. VIEIRA. E-mail: <emeireles@ufpa.br>.

2 Universidade Federal do Ceará, Faculdade de Educação, Programa de Pós-Graduação em Educação. Fortaleza, CE, Brasil.

Acknowledgments: Universidade Federal do Pará, Pró-Reitoria de Pesquisa e Pós-Graduação and Fundação de Amparo e Desenvolvimento à Pesquisa from same University for the financing of translation from original Portuguese version to the English version. 
Psychotherapy is the central theme in the work of Carl Rogers, founder of the Person-Centered Approach (PCA). Regarding the expansion of his ideas in other areas of human relationships, it was in this field that Rogers produced the largest volume of research and achieved world recognition as the pioneer in empirical investigation in the therapeutic process, as well as its consequences, both for the client and the therapist.

Rogers (2001) defines that the objective of the clients who seeks for psychotherapy is to become what they really are. According to the author, this means that the individual who undergoes the therapeutic process "Moves away from what he is not, from being just a facade. He is not trying to be more than he is, with the attendant feelings of insecurity and the defense mechanisms this implies" (Rogers, 2001, p.199). In another article, Rogers (1978) suggests a description of the person who comes out of a successful process of psychotherapy based on what he calls "fully functioning person". Both descriptions of the objective of the therapy and of the person emerging from this process, value the harmony between the organism and the self, the recognition by the individual of their own experience and, therefore, a kind of harmonical encounter with themselves, or, as put by Rogers, an "internal agreement" (Rogers \& Kinget, 1977).

Vieira and Freire (2006) question the PCA in its ethical dimension based on the radical alterity ethics, by Emmanuel Lévinas. According to this perspective of ethics, subjectivity would be built based on the relationship with the absolute Other, in a vertical relation that is not amenable to synthesis (Freire, 2002). Vieira and Freire (2006) postulate the necessity of thinking of an approach that is ex-centric to the person, an approach that understands the individual not based on the idea of integration of the experience, but that recognizes a dimension of estrangement in their constitution. This distances PCA from the perspective under which it is normally thought, that is, of an integration and recognition of the experience by the self.

Vieira (2009 p.17), following the reflections previously mentioned, discusses about something different from the balance so preconized by Rogers in his publications, and claims that "More than an individual who gets to know themselves, psychotherapy produces

232 some subjectivity that is strange, as it is characterized particularly by the unpredictability and surrendering to the flow of existence". Psychotherapy in the PCA, for this author, would be a lot closer to identifying differences than to recognizing oneself.

Amatuzzi (2001), even belonging to a different philosophical perspective than the elaborated by the authors cited, recognizes a dimension of alterity in the therapeutic process when he claims that "... the authentic speech decides and triggers something. It not only translates, but keeps and promotes an intention, which makes it, in a certain way, past as a mere intention, and originating new interventions inside a move" (Amatuzzi, 2001, p.24). Amatuzzi, therefore, as well as Vieira (2009) and Vieira and Freire (2006), point to the consideration of some estrangement present in authentic discourse. Thus, this would be a discourse that could dislocate the individual from a fixed place, which, according to Vieira and Freire (2006), would demonstrate its ex-centric characteristic.

The considerations brought by the cited authors question the notion that psychotherapy would be an encounter with oneself, or the rescue of a lost balance the insertion in the social. We can say that, according to these authors, there is a tension in the human constitution which is evident in psychotherapy and that this tension, rather than being suppressed by an internal agreement, deserves to be heard.

This article seeks to understand how the estrangement referred to by Amatuzzi (2001), Vieira (2009) and Vieira and Freire (2006) are shown in the psychotherapeutic context, as well as to discuss the possibilities of the opening to alterity present in PersonCentered Therapy (PCT). In order to meet these objectives, it is taken as a starting point the premise advocated by Rogers (1994) as an essential aspect for the progress of a therapeutic change of personality, that is, client's perception regarding the process in question. For such, it was used a client's testimonials about her own psychotherapy, taken session by session by Rogers and his assistants published in "Client Centered Therapy", 1951.

We will present the descriptions given by the client as well as the comments made by Rogers regarding these statements. Positions of criticism alternate with these topics, anchored in ethics of the radical alterity, of Lévinas (1998; 2000). 


\section{Lévinas and the radical alterity ethics}

Speaking of Lévinas, a Franco-Lithuanian philosopher of vast production and complex thinking, means, before anything, subverting the order from which, usually, questions posed by Philosophy are normally thought of. Lévinas, instead of approaching the individual, questions them. Such operation is carried out by this philosopher through the primacy of the relationship with the Other in subjectivity, which gives his theory the denomination of ethics of radical alterity and institutes the relation with alterity as necessarily vertical and of impossible reciprocity. It is the primacy of ethics over ontology (Pivatto, 2000).

Lévinas (2000) contrasts the Same to the Other, a dimension of the human being that cannot be captured by institutional knowledge, something that always escapes. According to Freire (2002), in Lévinas Philosophy, the Infinity within us is what makes us human. This means that, even though we are finite, we are like beings that live beyond our death.

Thus, Lévinas holds in check the project of modern civilization, as the self-sufficiency state, which he calls "fruition", to which modernity has raised the human. It is broken by the relation with the absolute other, in a way that the human is only humanized from the moment that he recognizes the difference. This means that the relationship with alterity is, from the beginning, the subjection of the same (subject centered on his fruition) by the other. Or still, the interruption of the need for the institution of desire, that which goes beyond my being and reveals itself in its own mystery.

'The recognition of the difference, for Lévinas (1998), takes place through the revelation of the Face of the Other, which is not phenomenal, because if it were, it could be captured by a definite image. In an interview with Poirié (2007), Lévinas says: the face (visage) is not of the order of the visa, is not an object, it is what the appearance retains an externality that is also a call - or imperative because of its responsibility... . If you conceive it as a photographer's object, surely you are dealing with an object like any other object. But if you find the face, that responsibility is in this strangeness of others and in their misery' (Poirié, 2007, p.85).

The meeting that Lévinas referred to above alludes to another consequence of the relation to alterity, irrespective, that for this philosopher, to paraphrase Dostoyevsky, "We are all guilty of everything and everyone before all, and I, more than the others" (Lévinas, 1998, p.90). Thus, the relationship with the radical Other is also of responsibility. For Lévinas, we are all responsible for others, nontransferable and individually. It is from this, then, that the philosopher in question defines ethics:

Behavior in which another person, who is strange and indifferent, who belongs neither to the order of his interests nor the one of his affections, however, concerns him. His alterity concerns him. Relation of another order than the knowledge, that the object is invested by knowing, what passes through the only mode of relationship with human beings. Can someone be for onelwithout being reduced to an object of pure knowledge? Situated in an ethical relation, the other man remains another (Poirié, 2007, p.84).

Talking about ethics and alterity, therefore, means opening up for the difference of the other. Not for identification, but host, as warns Pivatto (2000). This means that ethics implies passivity, lack of expectation of possession or control, or, as Lévinas (1998) says, a "Here I am" as a gift to others. That is why Freire (2001 p.) states that Lévinas ethics is a "Consideration about hospitality, as welcome the arrival of the other, that is overturned by the hostage condition" (section Levinasian Ethics, paragraph 2) since the other who takes me over who I cannot exercise any control.

The mark of the difference from the other places me the "thou shalt not kill" (Freire, 2000; Lévinas, 1998), because, even if it is possible the murder of his physical organism, the mark of his difference is imposed on any instrument of power. For Bauman (2011),"taking the moral responsibility means not to consider the other as a specimen of a species or of a category, but as a single, and in doing up (becoming'chosen') the worthy state of the oneness" (p.88). Thus, the impossibility of the murder of the other, more than a powerful metaphor, it speaks of elevating, of the host of his difference and affectation by her.

On these writings, the thought of Lévinas is used to consider possibilities for listening to the strangeness in the field of client-centered therapy. Now we have a discussion about the therapeutic process in PCT and an analysis of the effects of estrangement felt by a client served by Rogers as a theme to think about the issue. 


\section{The therapeutic process}

More than a concern with developing a theory of personality, it was up to Rogers to describe how that changed along a therapeutic process. In the classic "On becoming a person", 1961, Rogers describes psychotherapy through seven stages that make up a continuum, that is, they must be understood as a dynamic process. This means "It is unlikely that in a sphere of their existence the client declares a total fixity, and in another sphere an absolute mobility" (Rogers, 2001, p.149).

The continuum that Rogers refers to in the passage above goes from a perceptual point of fixity about the self, so an unavailability to try new experiences, to openness to the New caused by the modification of the way the individual perceives themselves regarding their own experiences. According to Rogers (2001):

In the new immediate experiences that occur in these moments, feelings and knowledge interpenetrate themselves, the self is subjectively present in the experience, the will is simply the result of a harmonious balance toward organismic. Thus, as the process approaches this point, the person becomes a unit in motion. The individual has changed, but what seems to be more significant is the fact that the individual himself has become an integrated process of transformation (p.181).

Therefore, for Rogers, the therapeutic change takes place in the direction of a greater integration of the experience to the self. This means that the experience would need to be recognized as belonging to the organization of the individual's personality so that it could be integrated harmoniously in the relation between organism and self.

Following the discussion of the therapeutic process, Rogers (1978) describes what, according to his understanding, would be a person in full operation. According to his clinical observations, the author of PCT describes the following characteristics developed by the individual after passing through a PersonCentered Therapy: openness to his own experience; an experience of the here-and-now, and increased confidence in the organism as the most suitable way to 23 establish a sieve for the experiment.
Rogers (1978; 2001) acknowledges, therefore, features that repeat in people who undergo a successful therapeutic process and lists the various stages through which the subject passes. The author, however, makes an exception by stating that such a proposition is not normative because it only fulfills the role of describing the therapeutic process in general.

Thus, the steps of the therapeutic process described elsewhere and the "fully functioning person" would indicate some regularity in the therapeutic process. This happens as about the direction that often takes regarding the effects on the individual.

In terms of personality theory (Rogers, 1975), we can understand the consequences of psychotherapy from a tension presented in a triangle formed by the vertices of culture, self, and the organism. The person seeking help from a psychotherapist is faced with the following situation: on one hand, culture demands from the individual the fulfillment of the requirement of being someone worthy of love; on the other, there is the need to maintain the coherence of the description that person makes of himself, undermined by the force of an experience that is incongruent with their self-concept, and finally the organism seeks a way of expressing their needs. The conduit, thus, becomes diffuse, as it does not know which need to satisfy.

The goal of psychotherapy, therefore, would be the integration of the experience, which means appeasement of voltage presented at the vertices of the triangle described above. According to the description provided by the creator of the PCT, "Most of the total experience of the organism is incorporated directly into the self, or, more accurately, the self tends to be discovered in the total experience of the organism. The patient follows his'real'self, his organismic self" (Rogers, 1975, p.513).

The model of personality presented by Rogers (1975) tells us about the initial time of the therapy, a dividing line between self and organism. Then, the therapy having ended, this line would tend to become fluid, so that in the moment the experience occurs, it becomes difficult to discern what is self and what is organism because both would have the experience as a sieve for the meaning assigned to itself, and not an external standard. 
There is, however, a problem posed when the PCT deals with the issue of alterity. Rogers overvalues one dimension of integration of the individual with his experience, so that the wanted in the psychotherapeutic process is a greater integration of the experiences, until then denied or distorted by the individual. Thus, one ignores a dimension of strangeness in the constitution of the psyche and seeks to reduce it to what can be recognized by the self.

A finding that deserves relevance in this matter is that both descriptions provided by Rogers himself about the therapeutic work and in the speech made by clients in this kind of process are quite recurrent reports of experiences of estrangement from them. According to Vieira and Freire (2006, p.431). "It is not very rare in the clinic that we hear from clients in therapeutic processes considered successful phrases like: 'I went through a situation in which I did not know myself, I was surprised!"'.

As you can see in the passage above, the baseline therapy centered on the person may have as one of its purposes the individual's contact with something that seems strange to them, by unsaying a whole prior conception that they have about themselves. Rogers (2003, p.18), however, thinks this phenomenon in a logical identity when he affirms about the uniqueness of some meanings produced in the therapeutic process: "This is the first time that this organismic topic, which until now was denied to consciousness, is now freely present in consciousness".

The quote above shows us that instead of seeking to understand the meaning of the experience from their estrangement, Rogers prefers to think of it as a dynamic integration already known. This is why, later, he discusses about the experience of the therapy: "It's self-acceptance, because it is recognized as belonging to oneself and not as something unrecognizable... it is an experience of being integrated" (Rogers, 2003, p.19).

In order to have more empirical elements for the discussion of alterity in psychotherapy, we will proceed with the description prepared by a client who recorded her impressions about the psychotherapeutic process each session. As we will see below, it is clear in her speech the presence of the elements that point to moments of profound estrangement of herself.

\section{The description of therapy from the client's and the therapist's points of view: The opening and closing for alterity}

In the work "Client Centered Therapy", Rogers presents the therapy relationship as described by a client he calls Mrs. Cam, someone with some knowledge of Psychology and who was willing to describe how she perceived therapy session by session. This is a rich and rare exhibition, not only of facts worked in the sessions, but mainly of the experiences raised by the ongoing process, interspersed with comments by Rogers about an understanding of the process. At first, we will show the speech of the client and the understanding that Rogers elaborates on this. At a second moment, we will discuss the spaces for alterity present in this report, through questions raised from the ethics of radical alterity of Lévinas.

In the report after the second session, Mrs. Cam describes a sense of chaos and disorder, estrangement on a number of factors concerning experiences in the therapeutic encounter. This can be seen, for example, in the following passage:

... it is really humanly impossible to impose order and meaning onto this chaos: how wonderful it would be to lose the last drop of self-awareness, to lose my perception of this confusion as confusion... to merge more and more into the pleasant peacefulness and forgetfulness of the not-knowing. How strange it is that I can find peace succumbing to what seems to be chaos and disorder (Rogers, 1975, p.106).

In Rogers understanding, what happens with Mrs. Cam is nothing more than an appropriation of the experience by the self,"Without the necessity of rejecting it or twisting it, so there is naturally a feeling of freedom and unity associated with this experience" (Rogers, 1975, p.107).

If we take the problem of alterity as postulated by Lévinas and here already stated, there is an ethical question to be raised about the understanding developed by Rogers, which is of the assimilation of the strange aspect of the experience by a facet already known of the experience - the self. What emerges from Mrs. Cam's excerpt is that there is more to it than the mere assimilation of an experience: it shows a relationship of 
openness and acceptance of foreign elements to the experience.

The client's experience carries a character of exteriority. Instead of the assimilation by the self, her speech seems to indicate that it is the experience that redefines the description that she makes of herself. This shows an inversion of the logics under which psychotherapy is usually thought by Rogers. This reflection can be seen in Mrs. Cam's speech when she says: "We must allow that our experience tell us its own meaning: the moment someone tells us what it means, the same antagonism of a patient in war with himself happens" (Rogers, 1975, p.107).

It is because of thinking based on the logics of assimilation that Rogers (1975, p.108) observes that "If we allow the experience to tell us its own meaning... and we assimilate these fundamental meanings to the structure of the self... we would not have this inner tension so common to all of us. This is what Mrs. Cam seems to suggest". Rogers tries to fit Mrs. Cam's speech in his theoretical schemes and minimizes the positivity of the estrangement pointed by his client, reducing it to a matter of incongruence between self and the organism.

The questioning of the deafness to which we previously referred is based on Lévinas (1998), according to which the Other does not get to us through our vision, as, in spite of presenting itself as a Face and demanding from us "Thou shall not kill!", its Face is nonphenomenal, that is, it can not be captured by an image of itself. Therefore, more than some optics of alterity, Lévinas shows us the need for an otic action (hearing) the externality that makes us human and that tensions interiority all the time. Rogers seemed to be unaware of this hearing, as we can notice in his comments.

The attitudes of the therapist, especially their non-possessive love (Rogers, 1976), create conditions for the client to produce a new speech about herself and that the production of this discourse operate a deconstruction of her perceptual standard. More than a verbalization already ready and only not yet expressed, the report provided by Mrs. Cam shows unprecedented and estrangement, as it can be seen in the following passage:"It is interesting to discover that there are more things to express than I suspected, and there is an obscure satisfaction in the continuous effort to face obstacles; this continues to seem a pleasant and safe atmosphere in which to do things, but, if this atmosphere were weakened, I would incline myself towards another possibility" (Rogers, 1975, p.112).

Once again, Rogers (1975, p.113) emphasizes the idea of acceptance and recognition of the experience when, by commenting on the passage quoted above, he states: "Seeing another person, the therapist, accepting the experience rather than rejecting it... facilitates accepting the experience itself". For the American psychologist it is as if the self changed the perception of exteriority.

What seems to be shown by Mrs. Cam's report is another way, the one through which exteriority is affected by something external and strange in relation to itself - the organismic need. Returning to the point made earlier of a triangle composed of culture, self and organism, we can situate the organism as another-ofitself, because it has the function of expressing itself in therapy and serve as a sieve for the client's experiences. This idea seems to be confirmed in Mrs. Cam's speech when she says: "I am inclined to let myself be and enjoy the results, or let them sweep themselves away if they do not satisfy me; either way, the entire process of a psychological consultation seems to fight against any type of introspection and worry about oneself" (Rogers, 1975, p. 116).

Regarding the previous passage, Rogers (1975, p.117) outlines a recognition of the implied difference in the therapeutic process when he claims that, for Mrs. Cam, "... the intellectualized and introspective interest decays in favor of a more primitive experience" . This outline of reception of the different reappears when the author comments on the despair and hopelessness manifested by his client at a later stage of the therapeutic process: "Such desolation, according to the experience of the author, will only probably happen in situations of basic and ample reorganization of the self"(Rogers, 1975, p.124).

Regarding the reflections taken in this work, the Rogerian work cannot be considered completely allergic to alterity. According to Vieira and Freire (2006), it is possible to think of an approach that prioritizes an excentricity of facilitative attitudes, as opposed to principles of identity present in its original formulation. This emphasis on the ex-centricity may do more than refer 
the individual to an established truth about themselves, but move them to a center of familiarity toward contact with the strangeness of their experience.

Another point of inflexion regarding the opening to alterity is in the concept of experiencing proposed by Gendlin and taken by Rogers. Messias and Cury (2006) invite us to reflect upon the impact of this conception for the client-centered therapy. Experiencing, according to some authors, would be a neologism which indicates the process and the possibility of direct reference to some affection, instead of valuing its intellectual content. Affection considered as disruptive, as estrangement, loses its power to be captured by the intellect, which, by its nature, tends to shape it to known standards. Insofar as we value its direct access, without a cognitive mediation through language, then we have doors and windows open to foreign visitors, as taught by the metaphor proposed by Lévinas (2000).

Another way to access the difference can be seen in Amatuzzi's (1994, p.25). Idea of "authentic speech" Based on Merleau-Ponty. The author divides psychotherapy in moments of "secondary expression" and "authentic speech". The first concept refers to the speech already ready and recognized by the individual, therefore, mere repetition. The latter, on the other hand, happens in the immediacy of the here-and-now of the therapeutic relationship and opens new possibilities. In this sense, Vieira and Freire (2006, p.430) claim that "... authentic speech triggers new intentions... [moving away from] a perspective of essentiality... the speech acquires ... a life of its own, as if it reconfigured the individual's intention and not the other way around".

\section{Final Considerations}

Some factors should be highlighted regarding Rogers dealing with alterity. The first one refers to scientistic claims early in his career and his subsequent commitment to an if-then logic to undergo psychotherapy. Even exposing the resulting conflict (Rogers, 2001), in the article "Persons or Science? A philosophical problem", Rogers took a long time to see that his findings did not fit in the closed world Psychology Academy (Rogers, 1986). His initial commitment to a modern scientific project necessarily kept him distant from a thought he could conceive of the strange, as it is known, it has been up to science, since the beginning, the role of predicting and controlling, dealing with regularity. For this reason, some of his most famous texts, edited by Wood (1994), seek regularity, be it in the therapeutic process or in the transformations deriving from it.

Another important factor that must be taken into account herein is the difficulty thinking of alterity from an applied type of knowledge. The dialogue between Rogers and Buber, which occurred in 1959, shows this challenge, when authors disagree exactly because of the lack of understanding of both regarding the place from which they were speaking - Philosophy and Psychology.

This results in a necessary alert. This work is not intended in any way to fit philosophical reflections on the practice of psychotherapy, as if it recognized in Philosophy a technical dimension that is not intended for it. The intention is more in the field of implications, that is, the proposition of problems for the practice of psychotherapy, beyond its technical facet, to which, many times, it is reduced. It is known that ethical issues are implicated in this process, not to say political ones. After all, thinking approach of Psychology, whatever it may be, having alterity as motto, means alerting for the necessity for it not to contribute in the standardization of the human, and, therefore, ignore what makes us human, that is, the absolute and radical other, which is irreductible to a standardized sameness.

That being said, we can point the need to rethink the understanding of the base of person-centered Psychotherapy in its ethical aspects as significant consequences of this text. If, for Rogers, what mattered was patience, personality, and other topics of the kind, we are given the possibility to redefine concepts and understandings.

This change of perspective is harbored on the conceptions developed by Dutra (2004) and Figueiredo (2004) on Contemporary Clinical Psychology. For these authors, the clinic, more than a place, concerns ethics. It is a way of opening and understanding the unsaid in the social field.

In this sense, the organism, as a privileged arena of expression during psychotherapy, seems to be a way 
to understanding the strangeness in the psychic dynamics. The virulence in this strangeness that accompanies the organismic experience is capable of undermining concepts established by the individual about themselves and indicates new possibilities of dealing with the PCA with the other. More than an appropriation and familiarization of the strangeness by the self, as pointed out by Rogers, the speech of Mrs. Cam leads to questioning this construct based on a strange experience, which means it is not necessarily explained.

Thus, besides an encounter with oneself, to which Rogers many times refers in his texts, the personcentered psychotherapy points as one of its possible effects a clash with the radically different. For such, it needs to disentangle itself from the idea of the assimilation of the experience by the self, and to acknowledge the deconstruction of the self by the exteriority presented by the experience per se. More than a theoretical exercise or change of nomenclature, this indicates a political discussion of PCA in the way it deals with the different as different.

\section{Rerefences}

Amatuzzi, M. M. (2001). Por uma psicologia humana. Campinas: Alínea.

Amatuzzi, M. M. (1994). O resgate da fala autêntica: filosofia da psicoterapia e da educação. Campinas: Papirus.

Bauman, Z. (2011). Vida em fragmentos: sobre a ética pós-moderna. Rio de Janeiro: Jorge Zahar.

Dutra, E. (2004). Considerações sobre as significações da psicologia clínica na contemporaneidade. Estudos de Psicologia (Natal), 9(2), 381-387.

Figueiredo, L. C. M. (2004). Revisitando as psicologias: da epistemologia à ética das práticas e discursos psicológicos. Petrópolis: Vozes.

Freire, J. C. (2000). O lugar vacante do Outro nas psicologias da modernidade tardia (Tese de doutorado não-publicada). Programa de Pós-Graduação em Psicologia Experimental, Universidade de São Paulo.

Freire, J. C. (2001). As psicologias na modernidade tardia: 0 lugar vacante do outro. Psicologia USP, 12(2), 73-93.
Freire, J. C. (2002). O lugar do Outro na modernidade tardia. São Paulo: Anna Blume Fortaleza.

Lévinas, E. (1998). Ética e infinito. Lisboa: Edições 70.

Lévinas, E. (2000). Totalidade e infinito. Lisboa: Edições 70.

Messias, J. C. C., \& Cury, V. E. (2006). Psicoterapia centrada na pessoa e o impacto do conceito de experienciação. Psicologia: Reflexão e Crítica, 19(3), 355-361.

Pivatto, S. (2000). Ética da alteridade. In M. Oliveira (Org.), Correntes fundamentais da ética contemporânea (pp.79-99). Petrópolis: Vozes.

Poirié, F. (2007). Emmanuel Lévinas: ensaios e entrevistas. Manaus: Perspectiva.

Rogers, C. R. (1975). Terapia centrada no paciente. São Paulo: Martins Fontes.

Rogers, C. R. (1976). Algumas lições de um estudo de psicoterapia com esquizofrênicos. In C. R. Rogers \& B. Stevens. Depessoa para pessoa: o problema de ser humano (pp.211-224). São Paulo: Pioneira.

Rogers, C. R. (1978). Liberdade para aprender. Belo Horizonte: Interlivros.

Rogers, C. R. (1986). Em retrospecto: quarenta e seis anos. In C. R. Rogers \& R. L. Rosenberg, A pessoa como centro (pp.29-45). São Paulo: EPU.

Rogers, C. R. (1994). As condições necessárias e suficientes para a mudança terapêutica da personalidade. In J. K. Wood (Org.), Abordagem centrada na pessoa (p.155-177). Vitória: Ceciliano Abel de Almeida.

Rogers, C. R. (2001). Tornar-se pessoa. São Paulo: Martins Fontes.

Rogers, C. R. (2003). A essência da psicoterapia: momentos de movimento. In A. M. Santos, C. R. Rogers \& M. Bowen. Quando fala o coração: a essência da psicoterapia centrada na pessoa (pp.15-23). São Paulo: Vetor.

Rogers, C. R., \& Kinget, G. M. (1977). Psicoterapia e relações humanas (Vol. 1-2). Belo Horizonte: Interlivros.

Vieira, E. M., \& Freire, J. C. (2006). Alteridade e psicologia humanista: uma leitura ética da abordagem centrada na pessoa. Estudos de Psicologia (Campinas), 23(4), 425-432. doi: 10.1590/S0103-166X2006000400010.

Vieira, E. M. (2009). Sobre a proposta de conhecimento presente na teoria rogeriana ou da sabedoria residente na ignorância. Revista do NUFEN, 2(1), 4-19.

Wood, J. K. (Org.). (1994). Abordagem centrada na pessoa. Vitória: Ceciliano Abel de Almeida.

Received on: 23/5/2011

Final version on: 11/5/2012

Approved on: 28/5/2012 